\title{
Erosion and vegetation cover in road slopes hydroseeded with sewage sludge
}

\author{
By: Juan de Oña, Andrés Ferrer and Francisco Osorio
}

This document is a post-print versión (ie final draft post-refereeing) of the following paper:

Juan de Oña, Andrés Ferrer and Francisco Osorio (2011) Erosion and vegetation cover in road slopes hydroseeded with sewage sludge. Transportation Research Part D, 16, 465-468.

Direct access to the published version: http://dx.doi.org/10.1016/j.trd.2011.04.002 


\title{
STUDY OF EROSION AND VEGETATION COVER IN ROAD SLOPES HYDROSEEDED WITH SEWAGE SLUDGE
}

\author{
De Oña, J. ${ }^{a}$, Ferrer, A. ${ }^{a}$ and Osorio, F. ${ }^{a, b, *}$ \\ ${ }^{a}$ Department of Civil Engineering - Transport Section; University of Granada; Campus de \\ Fuentenueva, s/n; 18071; Granada - SPAIN; e-mail.- jdona@ugr.es \\ ${ }^{b}$ Department of Civil Engineering - Environment Section; MITA Research Group, Institute of \\ Water; University of Granada, SPAIN \\ ${ }^{*}$ Corresponding author address.- Department of Civil Engineering; Environment Section; \\ University of Granada; Campus de Fuentenueva, s/n; 18071; Granada - SPAIN; Telephone.- \\ 34958242931; Fax.-34958242931; e-mail.- fosorio@ugr.es
}

\begin{abstract}
This study was based on 12 pilot plots: six cut slopes and six fill slopes, each with an area of $100 \mathrm{~m}^{2}$. In each group of six plots, one plot received no treatment at all; one plot was hydroseeded in the conventional way; three were hydroseeded with different sludge dosages, and one received only sewage sludge and seeds with no slurry mix. The study was carried out in two complete vegetation cycles over a period of two years. To assess the vegetation cover, images of the plots were taken with the ARCMAP software application, and rasterized. To measure the eroded sediment, traps were installed in each pilot plot, to collect the sediment that had been carried there by the run-off. After two vegetation cycles, in which an untreated control plot was compared to plots hydroseeded with sewage sludge, the measured erosion was on average 2.2 times lower in the cut slopes and 3.5 times lower in the fill slopes. The performance of the plot where sewage sludge and seeds were applied without the slurry mix was very similar to the performance of the rest of the hydroseeded plots, which had received sewage sludge with the slurry mix. Consequently, the results of our study show that for the restoration of road embankments, all conventional hydroseeding components, except for seeds, could be replaced by sludge.
\end{abstract}


Keywords: erosion; road embankment; sludge; landscape restoration; waste management

\section{INTRODUCTION}

The plants that grow on roads embankments protect the slopes from soil erosion and reduce visual impact (Blunt et al., 1994). The soil in newly constructed road embankments is generally not very fertile, poorly structured, and low in nutrients (De Oña and Osorio, 2006a). This limits the growth and development of vegetation and substantially reduces the protection offered against erosion. Consequently, measures are taken to improve the soil characteristics of slopes on newly constructed roads (e.g. hydroseeding).

Sludge is a by-product obtained from wastewater treatment processes (Singh and Agarwal, 2008). Currently, in Europe, there has been a spectacular increase in sewage sludge. The problem generated by these growing sludge quantities can only be solved through the effective management and reuse of this waste. As sewage sludge contains high levels of the principal plant nutrients, $\mathrm{N}$ and $\mathrm{P}$, and is rich in organic material, its application to soil is a common practice throughout the world (De las Heras et al., 2005; Gerhardt et al.,1997), subject to strict regulations to guarantee the safe recycling of sludge because it may contain potentially harmful materials such as heavy metals (Dai et al., 2006; McGrath et al., 1994).

In this sense, the use of sludge to restore road embankments causes fewer problems from the perspective of health and waste management since food crops are not grown on such embankments (Tandi et al., 2004). Previous studies have focused on the viability and possible benefits of applying sewage sludge to road embankments (De Oña and Osorio, 2006a, 2006b; De Oña et al., 2009) but did not compare results with those obtained using hydroseeding. Those studies used the Universal Soil Loss 
Equation to estimate soil loss. This study provides actual measurements of the quantity of eroded material instead estimated values.

The main objective of this study is to analyze the use of sewage sludge in treatments for road embankment restoration (e.g. hydroseeding), and study its effect on the vegetation cover and erosion of the slopes.

\section{EXPERIMENTAL METHODS}

\subsection{LOCATION AND CLIMATE CONDITIONS}

In this study, 12 experimental plots on road embankments ( 6 on cut slopes and 6 on fill slopes) were laid out on a road in Arjona (municipality in the province of Jaen, Spain). Their approximate altitude was 317 meters above sea level. All plots had a southeast orientation and a slope of $2 \mathrm{H}: 1 \mathrm{~V}$

Arjona has a seasonal-rainfall oceanic bioclimate with a meso-Mediterranean thermotype, characterized by a dry subhumid ombrotype and a mild warm thermal type. It has a mean annual temperature of $17.31^{\circ} \mathrm{C}$ and a mean annual rainfall of $415.80 \mathrm{~mm}$ mainly during the autumn and winter months (Data source: Agencia Estatal de Meteorología, Spain).

\subsection{CHARACTERISTICS OF THE PILOT PLOTS}

The surface area of each plot was $100 \mathrm{~m}^{2}$. A metallic Gerlach trough (Gerlach, 1967) (see Figure 1), measuring $2 \times 2 \mathrm{~m}$, was placed at the center of each plot to collect runoff and sediment. Each trap consisted of a broad funnel that channeled water through a tube into a sealed receptacle where the eroded material was stored.

\section{(FIGURE 1)}

Each receptacle had a volume of 50 liters. Since the traps had an area of $4 \mathrm{~m}^{2}$, a rainfall event of 15 liters per $\mathrm{m}^{2}$ was enough to fill them. Consequently, the lid of this receptacle had six equidistant perforations located at the same level. In this way, the water fell equally through each of the six perforations. One of these perforations was 
connected to another receptacle that was able to collect a sixth of what would have been lost in the event that the first container was filled. With this information, it was possible to mathematically calculate the total eroded material.

\subsection{EXPERIMENTAL DESIGN AND EXECUTION}

Conventional hydroseeding $(\mathrm{CH})$ is a mechanical planting process in which an area is sprayed with slurry of seed, mulch or stabilizer, fertilizer, and additives.

For all plots (whether cut or fill), the same type and amount of seed $\left(35 \mathrm{~g} / \mathrm{m}^{2}\right)$ was used. The other components of the hidroseeding were: cereal straw was as mulch; a quick-release NPK as fertilizer; and, a medium cationic polyelectrolyte with a high molecular weight, made from a cationic acrylamide derivative as additive.

As part of our study, sewage sludge was added to the other components of the mix.

The experiment involved treating each of the six plots, located on cut slopes and fill slopes, with different sludge dosages. For the purposes of the study, the sludge was sprayed on four plots, whereas the other two were used as control plots (see Table 1). One of the control plots was conventionally hidroseeded without sludge, and the other plot received no treatement.

(TABLE 1)

The characteristics of the sludge (i.e. its high moisture content) meant that it had to be applied first in order for conventional hydroseeding equipment to be used. Consequently, sewage sludge was sprayed on the plots at the previously mentioned concentrations. The plots were then hydroseeded in the conventional way.

\subsection{SOIL AND SLUDGE CHARACTERISTICS}

Before being hydroseeded, the cut slopes had no topsoil in contrast to the fill slopes, which did have topsoil, since topsoil is generally added after the construction of embankments in fill slopes. Consequently, the fill slopes possessed better agronomic 
properties than the cut slopes since the subsoil in both sites was very compact, impermeable, and rich in clay and lime.

Before the hydroseeding process, various laboratory analyses were performed on the soil and sludge (agronomic parameters and heavy metal content). Table 2 gives the values of the agronomic parameters.

(TABLE 2)

From an agronomic point of view, the sludge showed better parameters for plant growth because of its richness in organic material, nitrogen, and fulvic acids. Embankment soils had a fulvic acid content of less than $1 \%$, whereas the sludge had a fulvic acid content of $7 \%$ (see Table 2). This is important since fulvic acid is decomposed organic material available for vegetation (Eyheraguibel et al., 2008). The total humic extract in the soils was also less than $1 \%$ in contrast to the sludge, where it was $8.4 \%$. This extract is the sum of all of the humic acids (fulvic and humic), which represents the organic fraction of the soluble soil in the alkaline medium necessary for the formation of an evolved soil and vegetation (Eyheraguibel et al., 2008).

Another important parameter, which reflects intrinsic soil quality is the carbon/nitrogen ratio. This ratio is indicative of the rate of mineralization that should occur for a given type of organic material in the soil as well as the type of humus. The lower the $\mathrm{C}: \mathrm{N}$ ratio, the higher the rate of mineralization of the organic material. This means that the soil quality is also better. Since the C:N ratio of the sludge was found to be lower than that of the soil, it is probable that the addition of sludge will improve the quality of the soil where the seeds are planted (Aguilo, 1981; Dorgelo and Leonards, 2001).

Another indicator of the presence of nitrogen is Kjeldahl nitrogen, which in the case of the different soils was insignificant (lower than 1\%), whereas in the sludge, it was $5.5 \%$. Since this parameter also refers to the amount of nitrogen present in soil and sludge, its impact is the same as that of the carbon/nitrogen ratio. 
Also crucial is the percentage of organic material, which was much greater in the sludge than in the soil. Organic material is a necessary source of soil nutrients. It provides support for vegetation, as well as a base for the formation of a structured soil with texture. It is also a means of protecting the soil against water erosion (Veum et al., 2009).

The sludge was found to have a greater quantity of heavy metals than the soil although the amount was lower than the limit established in the European Union regulations concerning the use of sewage sludge in farming (Council Directive 86/278/EEC, 1986).

\subsection{MONITORING AND CONTROL}

\subsubsection{Vegetation cover}

The vegetation cover was calculated using a mixture of conventional methods, manual systems, and modern systems based on photographic analysis (Kuechler and Zonneveld, 1988). The process was the following: first, photographs were taken of each plot during an on-site visual inspection; second, the pictures were rasterized with ARCMAP version 9.2.; next, the different colors in the images were detected in the raster, and; finally, a software application was used to count the number of pixels in each color. The total number of pixels and percentages in the image were calculated. Once the color percentages were obtained, it was necessary to identify what each color represented. In this case, percentages were calculated for the vegetation in each plot, and thus, the total vegetation cover in each plot was obtained.

The methodology used was found to have certain limitations resulting from the slope of the embankments and the height of the vegetation cover. As the photograph was taken from the highway, it was not an image of the surface plane since such a photograph could only have been obtained from the air. The other limitation was the the program's interpretation of pixel colors. In any case, the results of the software 
application were compared to on-site visual observations, and found to be quite satisfactory.

\subsubsection{Measurement of erosion}

The measurement of the erosion was performed by periodically visiting the plots. Sediments accumulated in the sediment traps were collected. Plots were monitored at least once a month though in periods of heavy rainfall, they were monitored somewhat more frequently.

In laboratory sediments were weighed. They were then dried at a temperature of $200^{\circ} \mathrm{C}$. After the sediments had been dried, they were weighed a second time, and the sediment content was obtained. This result was divided by the surface occupied by the traps to get an erosion value in $\mathrm{Kg} / \mathrm{m}^{2}$. This value was multiplied by the surface of the plots in order to ascertain the total quantity of the eroded material.

\section{RESULTS AND DISCUSSION}

Plots were monitored over a period of two complete vegetation cycles. This section presents the results for the first (April 2007 - March 2008) and the second period (April 2008 - March 2009).

\section{(TABLE 3)}

Table 3 shows the vegetation cover for the cut slopes and the fill slopes during the first and second vegetation cycle of the experiment. These results indicate that the greater the sludge dosages, the better the growth of the vegetation cover. The reason for this was the improvement in soil quality produced by the sludge. Similarly, it was found that during colder and drier seasons when conditions for plant growth are more adverse, there was a vegetation cover of over $20 \%$ on the slopes treated with sludge, whereas the cover was less than $20 \%$ on the slopes that did not receive any sludge dosage. 


\section{(TABLE 4)}

Table 4 shows the measured erosion for the cut slopes and fill slopes during the first and second vegetation cycle of the experiment. The final results are the sum of the data for both periods.

For the first vegetative period (April 2007 - March 2008), results reflect a general decrease in erosion as the sludge dosage increased with the exception of cut slope 5 that did not follow this pattern. Although this plot had an abnormally high erosion value, it was still lower than the erosion in plot 1, which received no treatment.

For the second vegetative period (April 2008 - March 2009), it was also found that a larger dosage of sludge led to less erosion. Even cut slope 5 clearly showed the expected result for its sludge dosage, and had a minimal soil loss during the second cycle. Plot 1, which was the control plot (with no treatment), had the worst result for both cut and fill slopes. It should be noted that erosion in the second year was an average of 7.2 times lower on cut slopes and 9.3 times lower on fill slopes. As could be expected, the development of a vegetation cover during the second period was extremely important, and the soil acquired a structure that was more resistant to erosion.

An analysis of the total erosion after two vegetation cycles reflected that the plots with the worst results were plot 1 , which received no treatment, followed by plots 2 , treated with conventional hydroseeding with no sludge added. In contrast, the plots with the best performance were those that were hydroseeded with a slurry mix that contained sewage sludge.

\section{CONCLUSIONS}

Hydroseeding is a practice that involves spraying a slurry mix made of various components for the landscape restoration of road embankments in order to increase 
vegetation cover on the embankment and reduce erosion. Based on the results of this study, it is possible to conclude that the addition of sewage sludge to the mix improved the performance of the embankment by reducing the erosion, and increased the vegetation cover more effectively than when sludge was not added to the slurry mix.

After two vegetation cycles, when plot 1 (control plot with no treatment) was compared to plots 3,4 , and 5 (plots hydroseeded with sewage sludge), the measured erosion was on average 2.2 times lower on the cut slopes and 3.5 times lower on the fill slopes. On the plots that had been conventionally hydroseeded with the sewage sludge, the measured erosion in the second vegetation cycle was drastically reduced in comparison to the real erosion measured after the first vegetation cycle (5.1 times lower on cut slope 3 which had the smallest reduction, and 4.7 times lower on fill slope 5 which had the smallest reduction).

Generally speaking, the performance of plot 6, where sewage sludge and seeds were applied without the slurry mix, was very similar to the performance of the rest of the hydroseeded plots that received sewage sludge with the slurry mix. Consequently, the results of our study show that for the restoration of road embankments, all conventional hydroseeding components, except for seeds, could be replaced by sludge.

\section{ACKNOWLEDGEMENTS}

This research was financed by the Public Works and Transportation Agency of the Regional Government of Andalusia, Spain (G-GI1002/IDI0). We thank Mr. Ignacio Mochón, from the Agency, for his support.

\section{REFERENCES}

Aguilo, J., 1981. Tratado del medio natural. Causas de destrucción del suelo, Tomo I, UPM, CEOTMA, INIA e ICONA, Madrid, Spain, 499-559. 
Blunt, S.M., Doken, T.C., 1994. In: D.H. Barker (Ed.), Erosion of Highway Slopes in Upland Walse: problems and solutions. Vegetation and Slopes: Establishment. Protection and Ecology. Proceedings of Conference, Oxford, ed. Thomas Telphord, for ICE, 95-107, 1994.

Council Directive of 12 June 1986 on the protection of the environment, and in particular of the soil, when sewage sludge is used in agriculture (86/278/EEC).

Dai, J., Chen, L., Zhao, J., Ma, N., 2006. Characteristics of sewage sludge and distribution of heavy metal in plants with amendment of sewage sludge. J. Environ. Sci-China 18 (6), 1094-1100.

De las Heras, J., Mañas, P., Labrador, J., 2005. Effects of several applications of digested sewage sludge on soil plants. J. Environ. Sci. Heal. A 40 (2), 437-451.

De Oña, J., Osorio, F., 2006a. Application of sludge from urban wastewater treatment plants in roads' embankments. J. Hazard. Mat. B131(1-3), 37-45.

De Oña, J., Osorio, F., 2006b. Using waste to reduce slope erosion on road embankments. P I Civil Eng-Transp , 159 (TR1), 15-24.

De Oña, J., Osorio, F., Garcia, P.A., 2009. Assessing the effects of using compostsludge mixtures to reduce erosion in road embankments. J. Hazard. Mat. 164 (23), 1257-1265.

Dorgelo, J., Leonards, P.E.G., 2001. Relationship between $\mathrm{C} / \mathrm{N}$ ratio of food types and growth rate in the snail Potamopyrgus jenkinsi (E.A. Smith). J. N. Am. Bethol. Soc., 20(1), 60-67.

Eyheraguibel, B., Silvestre, J., Morard, P., 2008. Effects of humic substances derived from organic waste enhancement on the growth and mineral nutrition of maize. Bioresource Technol. 99 (10), 4206-4212.

Gerhardt, T., Spliethoff, H., Hein, K., 1997. Thermische Nutzung vonKlärschlä mmen in Kraftwerksfeuer ungsanlagen. J. Entsorgungspraxis 3, 50-58. 
Gerlach, T., 1967. Hillslope troughs for measuring sediment movement. Revue de Géomorphologie Dynamique, Special Edition to the International Hydrological Decade, v.4, p 173.

Kuechler, A.W., Zonneveld, I.S., 1988. Vegetation Mapping. Handbook of Vegetation Science, Vol. 10. Dordecht, the Netherlands: Kluwer Academic.

McGrath, S.P., Chang, A.C., Page, A.L., Witter, E., 1994. Land application of sewage sludge: scientific perspectives of heavy metal loading limits in Europe and the United States. Environ. Rev. 2, 108-118.

Singh, R.P., Agarwal, M., 2008. Potential benefits and risks of land application of sewage sludge. Waste Manage. 28 (2), 347-358.

Tandi, N.K., Nyammangara, J., Bangira, C., 2004. Environmental and potential health effects of growth leafy vegetables on soil irrigated using sewage sludge and effluent. A case of Zn and Cu. J. Environ. Sci. Heal. B 39 (3), 461-471.

Veum, K.S., Goyne, K.W., Motavalli, P.P., Udawatta, R.P., 2009. Runoff and dissolved organic carbon loss from a paired-watershed study of three adjacent agricultural Watersheds. Agr. Ecosyst. Environ. 130 (3-4), 115-122. 
FIGURE CAPTIONS LIST

Figure 1.- Detail of the sediment trap and general view of the cut slope plots

Figure

Figure 1.- Detail of the sediment trap and general view of the cut slope plots

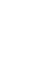 \\ the cut slope plots
}

\title{
FIGURE CAPTIONSLIST
}

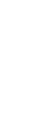

Figure

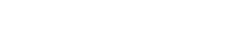

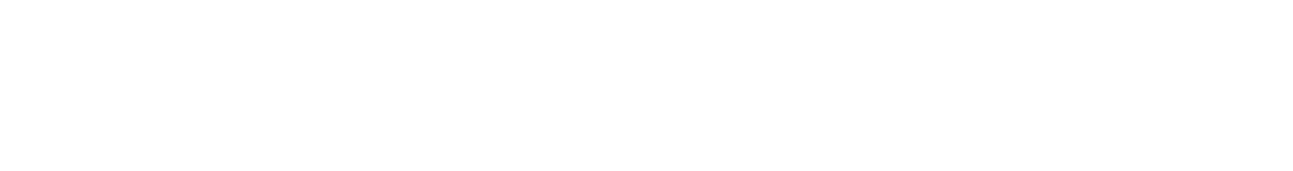




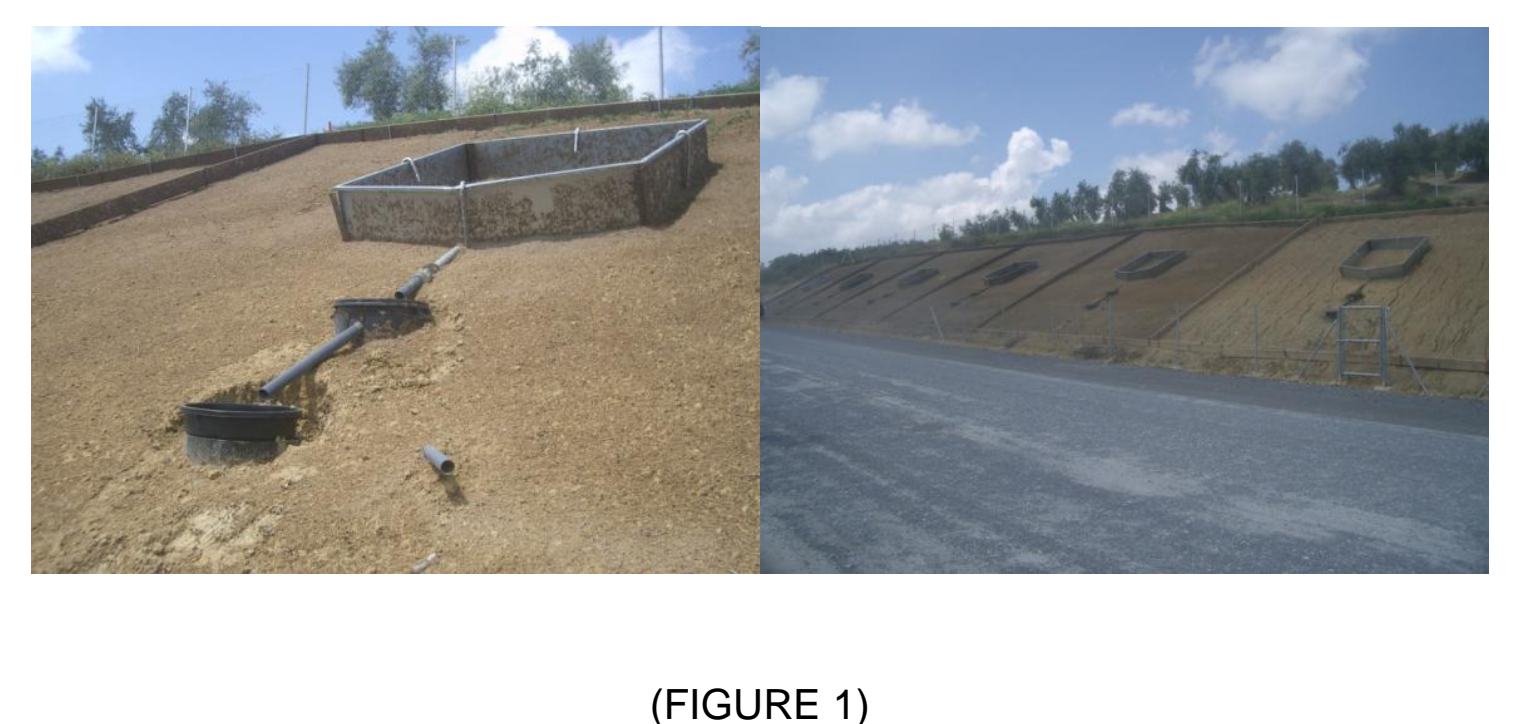

Figure (2)

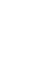

\author{
(FIGURE 1) \\ (FIGURE 1) \\ (FIGURE 1)

)
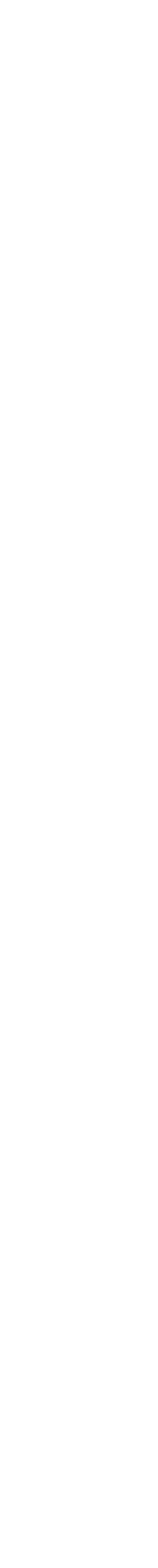

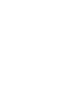

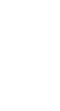
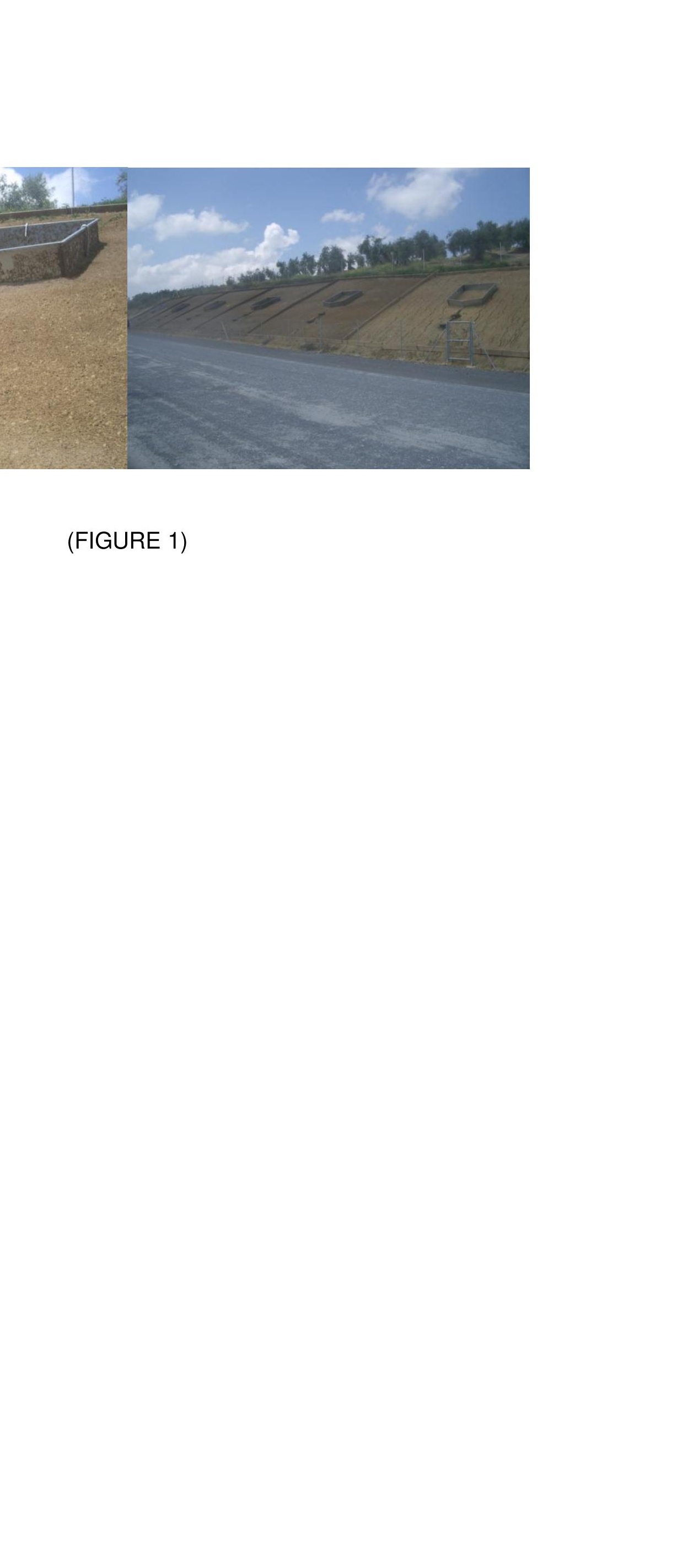
Table 1.- Plot names and dosages in the experiment

\begin{tabular}{lcccccc}
\hline Plot & $\mathbf{1}$ & $\mathbf{2}$ & $\mathbf{3}$ & $\mathbf{4}$ & $\mathbf{5}$ & $\mathbf{6}$ \\
\hline $\begin{array}{l}\text { Name for cut } \\
\text { slope }\end{array}$ & Cut1 & Cut2 & Cut3 & Cut4 & Cut5 & Cut6 \\
$\begin{array}{l}\text { Name for fill } \\
\text { slope }\end{array}$ & Fill1 & Fill2 & Fill3 & Fill4 & Fill5 & Fill6 \\
$\begin{array}{l}\text { Treatment } \\
\text { * }\end{array}$ & NH is Conventionally hydroseeded; SD1 is sludge dosage of $50 \mathrm{~g} / \mathrm{m}^{2} ; \mathrm{SD} 2$ is $200 \mathrm{~g} / \mathrm{m}^{2} ;$ and SD3 is $400 \mathrm{~g} / \mathrm{m}^{2}$ \\
\hline
\end{tabular}


Table 2: Agronomic Parameters in several soil and sludge samples

\begin{tabular}{lccccccc}
\hline Agronomic Parameters & $\begin{array}{l}\text { Soil } \\
\text { Cut2 }\end{array}$ & $\begin{array}{c}\text { Soil } \\
\text { Cut5 }\end{array}$ & $\begin{array}{c}\text { Soil } \\
\text { Cut6 }\end{array}$ & $\begin{array}{c}\text { Soil } \\
\text { Fill2 }\end{array}$ & $\begin{array}{c}\text { Soil } \\
\text { Fill5 }\end{array}$ & $\begin{array}{c}\text { Soil } \\
\text { Fill6 }\end{array}$ & SLUDGES \\
\hline Fulvic Acids \% & 0,3 & 0,4 & 0,5 & 0,8 & 0,6 & 0,6 & 7,0 \\
Humic Acids \% & $<0,10$ & $<0,10$ & $<0,10$ & $<0,10$ & $<0,10$ & $<0,10$ & $<0,10$ \\
Total humic extract \% & 0,1 & 0,2 & 0,3 & 0,4 & 0,4 & 0,3 & 8,4 \\
C:N Ratio \% & 8,7 & 10,8 & 13,0 & 7,5 & 7,7 & 8,0 & 3,4 \\
Organic carbon \% & 0,3 & 0,4 & 0,3 & 0,5 & 0,5 & 0,5 & 18,8 \\
Organic matter \% & 0,6 & 0,8 & 0,7 & 1,1 & 1,2 & 1,2 & 41,9 \\
Kjeldahl Nitrogen g/kg d.m. & $<0,50$ & $<0,50$ & $<0,50$ & $<0,70$ & $<0,70$ & $<0,70$ & 5,5 \\
pH & 8,4 & 8,2 & 8,4 & 8,3 & 8,3 & 8,3 & 7,3 \\
\hline
\end{tabular}


Table 3.- Vegetation cover in cut and fill slopes, period: april 2007 - march 2009

\begin{tabular}{cccccccc}
\hline Cut slopes & apr-07 & jan-08 & mar-08 & may-08 & oct-08 & nov-08 & mar-09 \\
\hline Cut1 & 0 & 0 & 2 & 2 & 1 & 1 & 5 \\
Cut2 & 0 & 5 & 55 & 82 & 20 & 28 & 80 \\
Cut3 & 0 & 10 & 70 & 90 & 40 & 32 & 85 \\
Cut4 & 0 & 8 & 42 & 84 & 35 & 20 & 15 \\
Cut5 & 0 & 5 & 63 & 97 & 70 & 30 & 65 \\
Cut6 & 0 & 3 & 50 & 95 & 50 & 25 & 35 \\
\hline Fill slopes & apr-07 & jan-08 & mar-08 & may-08 & oct-08 & nov-08 & mar-09 \\
\hline Fill1 & 0 & 15 & 20 & 69 & 90 & 40 & 63 \\
Fill2 & 0 & 60 & 85 & 90 & 40 & 15 & 70 \\
Fill3 & 0 & 55 & 95 & 95 & 97 & 60 & 80 \\
Fill4 & 0 & 45 & 90 & 97 & 85 & 53 & 85 \\
Fill5 & 0 & 25 & 75 & 78 & 85 & 47 & 90 \\
Fill6 & 0 & 20 & 50 & 85 & 60 & 34 & 75 \\
\hline
\end{tabular}


Table 4.- Total measured erosion, period: april 2007 - march 2009

\begin{tabular}{lccc}
\hline PLOT & $\begin{array}{c}\text { Erosion } 1^{\text {st }} \text { period } \\
\text { Apr 2007/mar 2008 } \\
\left(\text { dry matter } \mathrm{kg} / \mathrm{m}^{2}\right)\end{array}$ & $\begin{array}{c}\text { Erosion } \mathbf{2}^{\text {nd }} \text { period } \\
\text { Apr 2008/mar } 2009 \\
\left(\text { dry } \text { matter } \mathrm{kg} / \mathrm{m}^{2}\right)\end{array}$ & $\begin{array}{c}\text { TOTAL EROSION } \\
\text { Apr 2007/mar 2009 } \\
\left(\text { dry matter } \mathrm{kg} / \mathrm{m}^{2}\right)\end{array}$ \\
\hline CUT SLOPES & & & \\
Cut1 & 5,960 & 2,234 & 8,194 \\
Cut2 & 3,350 & 0,930 & 4,280 \\
Cut3 & 2,310 & 0,453 & 2,763 \\
Cut4 & 2,576 & 0,432 & 3,008 \\
Cut5 & 5,193 & 0,235 & 5,428 \\
Cut6 & 1,098 & 0,298 & 1,396 \\
FILL SLOPES & & & 8,977 \\
Fill1 & 6,522 & 2,455 & 4,171 \\
Fill2 & 2,709 & 1,462 & 3,046 \\
Fill3 & 2,662 & 0,384 & 3,884 \\
Fill4 & 3,686 & 0,198 & 0,701 \\
Fill5 & 0,578 & 0,123 & 2,748 \\
Fill6 & 2,624 & 0,124 & \\
\hline
\end{tabular}

